\begin{tabular}{|l|l|l||}
\hline \multicolumn{2}{|c|}{ PublisherInfo } \\
\hline \hline PublisherName & $:$ & BioMed Central \\
\hline \hline PublisherLocation & $:$ & London \\
\hline \hline PublisherImprintName & $:$ & BioMed Central \\
\hline \hline
\end{tabular}

\title{
Articles selected by Faculty of 1000: Streptomyces metabolism; diversity of Entamoeba transposons; Arabidopsis polymorphism pattern; miRNA effect on plant transcriptome; energy costs of gene duplications
}

\begin{tabular}{|l|l|l||}
\hline \multicolumn{2}{|c||}{ ArticleInfo } \\
\hline \hline ArticleID & $:$ & 3515 \\
\hline \hline ArticleDOI & $:$ & $10.1186 /$ gb-2005-6-7-333 \\
\hline \hline ArticleCitationID & $:$ & 333 \\
\hline \hline ArticleSequenceNumber & $:$ & 22 \\
\hline \hline ArticleCategory & $:$ & Paper report \\
\hline ArticleFirstPage & $:$ & 1 \\
\hline \hline ArticleLastPage & $:$ & 3 \\
\hline \hline & $:$ & RegistrationDate : 2005-6-24 \\
ArticleHistory & $:$ & OnlineDate 2005-6-24 \\
\hline \hline
\end{tabular}




\begin{tabular}{|l|l|l||}
\hline ArticleCopyright & $:$ & BioMed Central Ltd2005 \\
\hline \hline ArticleGrants & $:$ & \\
\hline \hline ArticleContext & $:$ & 130596677 \\
\hline
\end{tabular}

The Author(s)

\section{Summary}

Streptomyces metabolism; diversity of Entamoeba transposons; Arabidopsis polymorphism pattern; miRNA effect on plant transcriptome; energy costs of gene duplications

\section{Streptomyces metabolism}

Genome-scale analysis of Streptomyces coelicolor A3(2) metabolism. Borodina I, Krabben P, Nielsen J. Genome Res 2005, 15:820-829.

For the Faculty of 1000 evaluation of this article please see: http://genomebiology.com/reports/F1000/ gb-2005-6-7-333.asp\#Borodina

\section{Diversity of Entamoeba transposons}

Unexpected diversity and differential success of DNA transposons in four species of Entamoeba protozoans. Pritham EJ, Feschotte C, Wessler SR. Mol Biol Evol 2005, May 18.

For the Faculty of 1000 evaluation of this article please see: http://genomebiology.com/reports/F1000/ gb-2005-6-7-333.asp\#Pritham

\section{Arabidopsis polymorphism pattern}

The pattern of polymorphism in Arabidopsis thaliana . Nordborg M, Hu TT, Ishino Y, Jhaveri J, Toomajian C, Zheng H, Bakker E, Calabrese P, Gladstone J, Goyal R, et al. PLoS Biol 2005, 3:e196. 
For the Faculty of 1000 evaluation of this article please see: http://genomebiology.com/reports/F1000/ gb-2005-6-7-333.asp\#Nordborg

\section{miRNA effect on plant transcriptome}

Specific effects of microRNAs on the plant transcriptome. Schwab R, Palatnik JF, Riester M, Schommer C, Schmid M, Weigel D. Dev Cell 2005, 8:517-527.

For the Faculty of 1000 evaluation of this article please see: http://genomebiology.com/reports/F1000/ gb-2005-6-7-333.asp\#Schwab

\section{Energy costs of gene duplications}

Energy constraints on the evolution of gene expression. Wagner A. Mol Biol Evol 2005, 22:1365-1374.

For the Faculty of 1000 evaluation of this article please see: http://genomebiology.com/reports/F1000/ gb-2005-6-7-333.asp\#Wagner 